(C) Copyright by Wydawnictwa Naukowe Instytutu Lotnictwa

\title{
PREPARATION AND IMPLEMENTATION OF A TEST FLIGHT OF LIGHTWEIGHT, UNMANNED STRATOSPHERIC BALLOON WITH GOPRO CAMERA MOUNTED AND ANALYSIS OF ACQUIRED MATERIAL
}

\author{
Hubert Skoneczny \\ Center of Space Technologies, Remote Sensing Division, Institute of Aviation, \\ Al. Krakowska 110/114, 02-256 Warsaw \\ hubert.skoneczny@ilot.edu.pl
}

\begin{abstract}
Publication contains a description of the preparation and the implementation of a test flight of a stratospheric balloon with a mounted camera GoPro Hero3. Description includes: used equipment, its parameters, role in the success of the mission and the difficulties and limitations that the project team encountered during the preparation and implementation of the flight. The mission was attended by a team of six engineers and scientists from the Remote Sensing Division, who were also involved in the implementation of the HESOFF project. One of the main goals of the HESOFF project was to obtain aerial images on the Krotoszyńska Plate (woj. wielkopolskie) using the Unmanned Aerial Vehicle (UAV) and to carry out remote monitoring of oak stands. The primary goal of an experimental balloon flight was to check the technical operational capability and gain experience in planning and implementing this type of project. During the balloon raising, the video material was acquired in the form of a recording, which later was analyzed. On the basis of the collected information, the conclusions regarding the possibility of implementing a long endurance flight in the stratosphere, illustrating (using a multisensor platform) research surfaces of the HESOFF project were presented. The stages of implementation of the presented mission were divided into following parts: preparation of the flight with the completion of equipment and necessary documents (flight permission), proper flight realization, understood as the release of the balloon and identification of the place where the equipment landed, as well as analysis and presentation of the results.
\end{abstract}

Keywords: stratospheric balloon, photogrammetric flight, GPS, Unmanned Aerial Vehicle 


\section{INTRODUCTION}

The stratospheric balloons are very important sources of data in space research and observation of the Earth's surface in many scientific disciplines [1], and due to the nature of the application they can provide information, among others, on the state of the atmosphere from zones where a flight with observation plane is not possible. The first applications of balloons date back to the turn of the 19th and 20th centuries, and in Poland the pioneer in the implementation of such a mission was WBS in Legionowo. In 1938, just before the outbreak of World War II, a balloon called "Gwiazda Polski" (Star of Poland) was designed and constructed there - the largest stratospheric balloon based on classical production methods [2].

The stratospheric balloons consist of a coating that contains the carrier gas and the gondola attached below. Depending on the size of the coating and the material from which it was made, the load capacity of the balloon can range from several hundred grams up to several hundred kilograms, and the coating itself can be filled with a huge amount of gas, reaching up to several hundred thousand cubic meters [3]. At the Institute of Aviation, BOS-2 solution was implemented - an unmanned observation post designed for monitoring of forest areas from the air. The BOS-2 included a helium-filled balloon with innovative coating design - connections of the a strip of materials ensured the tightness of the coating throughout the whole year of observation for the balloon with shape of rotational body and size of $3 \times 10 \mathrm{~m}[4]$.

The use of stratospheric balloons in experimental and scientific research is very wide due to the possibility of effective and relatively inexpensive (depending on the scale of the project) observation. For example in the field of astronomy, which are not possible from the ground [5]. In addition, balloon platforms can be, at high altitudes, an economical alternative to space missions aimed at testing instruments, as well as in specific classes of observations - especially those requiring fast reactions, such as observations of comets [5].

As a part of work in the HESOFF project, a test balloon flight was carried out. The mission consisted of launching it into the stratosphere, up to a height of several kilometers, and acquiring video material during the stage of rising. The equipment used and its casing had to be adapted to the occurring atmospheric conditions in the stratosphere, i.e. to temperature fluctuations in the range from $-60^{\circ} \mathrm{C}$ to $0^{\circ} \mathrm{C}$ and the pressure drop, which decreases with the height and in the upper stratosphere, reaches $1 \mathrm{hPa}$. The place of the balloon release was the research area in the Piaski Forest District, and the entire equipment used in the mission was distinguished due to its function: the equipment placed in the gondola, which was used to acquire data and equipment responsible for rising and descent of the gondola, i.e. balloon and parachute. In the gondola GoPro Hero3 camera was placed and the necessary measuring and auxiliary devices such as: GPS Tracker, power source and parachute.

Description of the equipment used:

- Balloon: In the test mission, lightweight, unmanned stratospheric balloon was used as the camera carrier. The latex coating (300 $\mathrm{g}$ of its own weight and volume $\left.1.1-1.3 \mathrm{~m}^{3}\right)$ was filled with helium and released along with a gondola containing all the equipment. Balloon's filling was implemented directly before the flight with usage of the $5.6 \mathrm{~m}^{3}$ helium cylinder with mounted valve. According to the information from the manufacturer, the balloon was able to rise at a height of several kilometers while maintaining a constant speed of 5-6 m/s. The balloon's load capacity was up to $250 \mathrm{~g}$, so the selection of gondola equipment was strictly dependent on the weight limit.

- Camera: GoPro Hero3 Silver, as a necessary device used to acquire recording over the research area, was the basic element of the mission (except the balloon). The lifting capacity of unmanned platforms 
is very limited, therefore cameras should be used, whose mass-to-lens ratio and sensor size/sensitivity ratio is the best [6]. During the implementation of the mission the camera was equipped with internal power supply and an SD / SDHC memory card for saving the material. The camera was part of the equipment in the Remote Sensing Division, Institute of Aviation, and its small dimensions and weight $(74 \mathrm{~g})$ made it an ideal example suited to be used on a mission of this scale.

- GPS Tracker: in order to find a small gondola after landing, GPS Tracker - SPOT Gen3 was used. Given Tracker determines its location using a GPS satellite system and transmits all necessary data to communication satellites. Information then goes to the global network using a satellite dish, so that the final information about the location can be obtained, for example, by email, SMS or it can be tracked using an application dedicated to the Android system - SPOT ver. 1.0.8. During thr implementation of the mission, the application was used - the location of the Tracker was observed on the orthophotomap with refreshing every 2.5 minutes. According to the manufacturer's assurances, the Tracker is able to operate up to a height of $6500 \mathrm{~m}$ AMSL, but beyond that the position is no longer recorded.

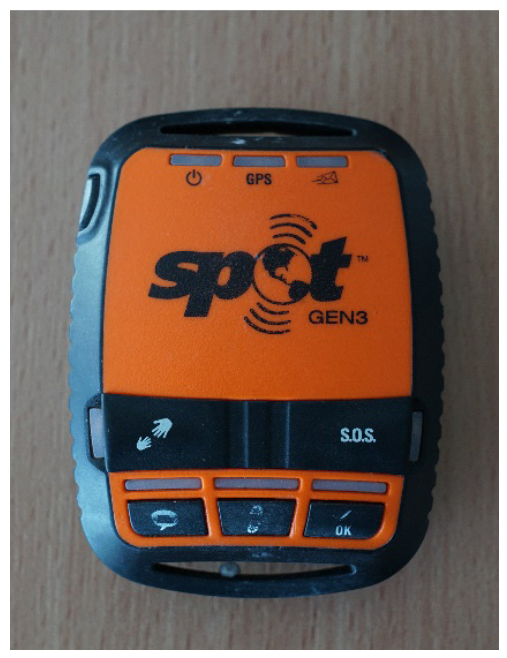

Fig. 1. GPS SPOT GEN3 Tracker placed in the stratospheric balloon gondola

In addition to the above-mentioned elements, the implementation of the mission required the use of: Arduino Nano v3.0 CH340 - programming platform based on $\mathrm{C}++$ language with power supply.

- Parachute - the success of the mission was dependent on ensuring a safe landing of a platform with a camera, that was about to fall from a height of several kilometers. A red parachute (for better visibility) with a lifting capacity of up to $300 \mathrm{~g}$ and own weight $10 \mathrm{~g}$ was used.

- Balloon gas - raising the balloon was provided by filling it with helium from a $5.6 \mathrm{~m}^{3}$ helium cylinder. The filling itself took place in the field right before the flight.

- Gondola - handmade casing $(14 \mathrm{~cm} \times 14 \mathrm{~cm} \times 10 \mathrm{~cm})$, built for the mission purpose, with usage of polystyrene foam, sponge, reinforced tape and red paint. Gondola was adapted to be connected with parachute and balloon, as well as its construction allowed all of the mission equipment to be properly and stable installed inside. Gondola consisted of lid and slot for the lens protected with Plexiglas.

- GPS module with power supply. 


\section{PREPARATIONS FOR MISSIONS AND FLIGHT EXECUTION}

The use of an unmanned free balloon requires a State permit, according to the area, where the balloon will be released [7]. Such permission was received after sending a request to the Polish Air Navigation Services Agency (PANSA) for the indicated area and date of flight. Obtained permission covered the period from 14 to 16 March 2018. Additionally, on the day of the flight, PANSA was informed about the planned start time. When planning a flight to such a high level, the atmospheric conditions, must be taken into account. The appropriate equipment protection was planned. According to the manufacturer's specifications, the balloon used in the mission can reach a height of several kilometers. In order to ensure the success of the mission, a casing made of foamed polystyrene, sponge and reinforcement tape was constructed. The task of casing was to protect the equipment from the direct influence of atmospheric conditions and from damages that would result from high altitude fall. A bright, red color was chosen for easier identification after completing the second stage of the mission. The stratospheric balloon flight was implemented on March 14, 2018 in the area of the Piaski Forest District ( $51^{\circ} 49^{\prime} 32^{\prime \prime} \mathrm{N}$ and $\left.17^{\circ} 06^{\prime} 16^{\prime \prime} \mathrm{E}\right)$. This area was chosen due to the fact, that at the indicated time, the field mission of the HESOFF project was carried out for the same research forest. HESOFF project assumed the regular implementation of photographic missions using, among others, unmanned aerial vehicle (UAV) and the QUERCUS.6 multi-spectral camera [8]. Acquired images were used to assess the condition of oak stands $[9,10]$. Aerial and satellite images, in turn are the basis for the analysis of the natural environment, and available raster images enable, among others, classification of land cover, water quality study, biomass analysis including quality of stands and development phase of crops [11].

The weather forecast for the day was very promising in terms of the mission of the stratospheric balloon - light cloudiness with wind up to $10 \mathrm{~km} / \mathrm{h}$, air temperature around $10^{\circ} \mathrm{C}$. The balloon was filled with helium and released around 2:00 pm.
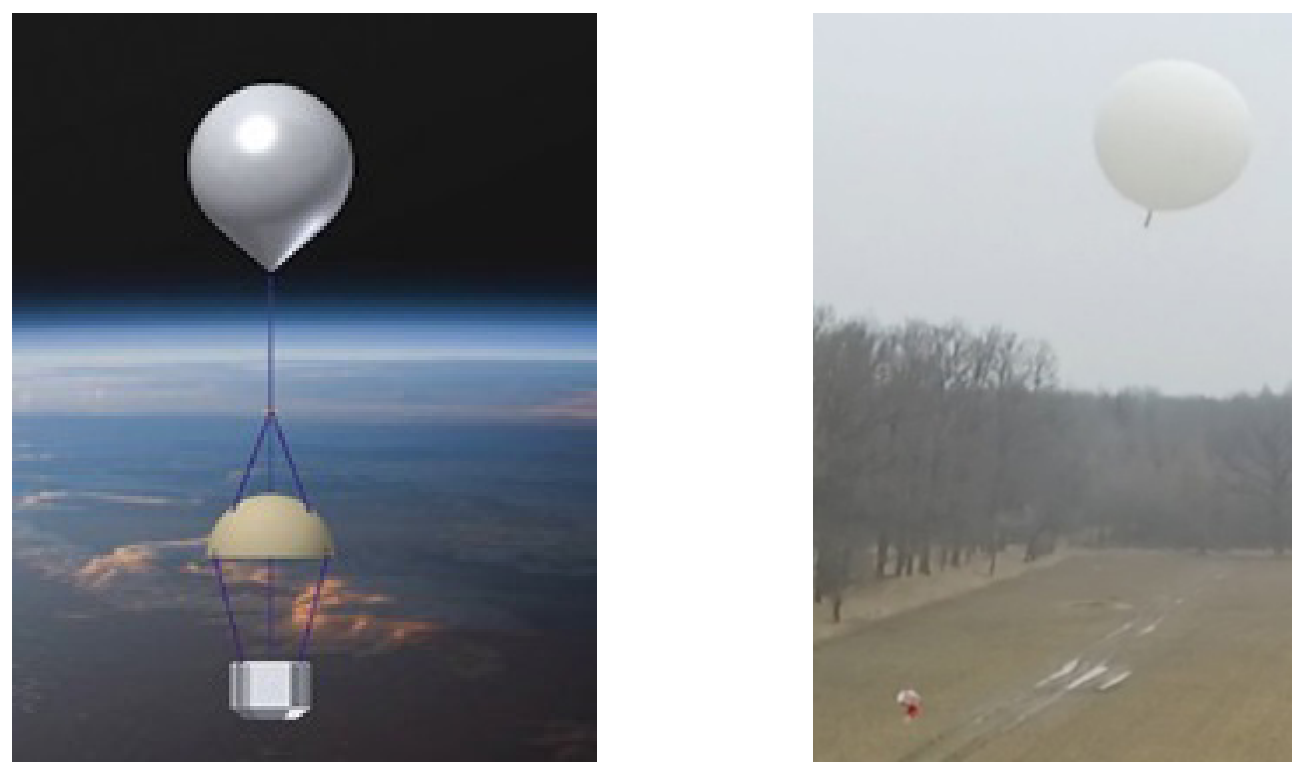

Fig. 2. a) The concept of connecting a gondola, parachute and balloon, which allows for the automatic activation of the parachute after cutting off the balloon [12], and b) the concept actually used in the mission - the balloon, regardless of the parachute, is permanently attached to the gondola. 


\section{INITIAL ASSUMPTIONS AND IMPLEMENTATION OF THE MISSION}

In one of the initial assumptions of the mission, an efficient mechanism to cut off balloon from the gondola, was taken into account. The aim of such a solution was to maintain full control over the altitude and time of flight, as well as, to prevent the falling gondola from being burdened by remains of a latex coating (in case of unlimited rising, the balloon would burst at the altitude around $20 \mathrm{~km}$ due to pressure difference). In addition, torn balloon coating could lead to entanglement of the parachute lines or the balloon would not reach the required tear height and would drift in the air for an indefinable time. Bearing in mind the indicated risks and knowing the parameters of the balloon, a flight lasting about one hour was assumed. In the initial phase of preparations, two concepts of cutting off the balloon were considered:

- Concept I - using a resistance wire connected to a battery, that after a set time burns the line on which the balloon was attached. Tests on earth, however, have shown $50 \%$ effectiveness of such a solution. Moreover temperatures (down to $-60^{\circ}$ in the lower stratosphere) negative impact on battery life, performance and stability must have been taken into account. In the end, the idea was abandoned. The use of a more capacious battery was not possible due to weight limitations of the gondola.

- Concept II - usage of the servo drive to release the balloon after a specified time. The purpose of this solution was to release the line after 1 hour by rotating the battery-operated arm by $90^{\circ}$. Shortly before the flight, however, this concept was also abandoned. The fact that disconnecting the balloon may occur, in an uncontrolled manner (earlier than expected), due to the instability of the gondola's flight caused by gusts of wind, resulted in forsaking this concept.
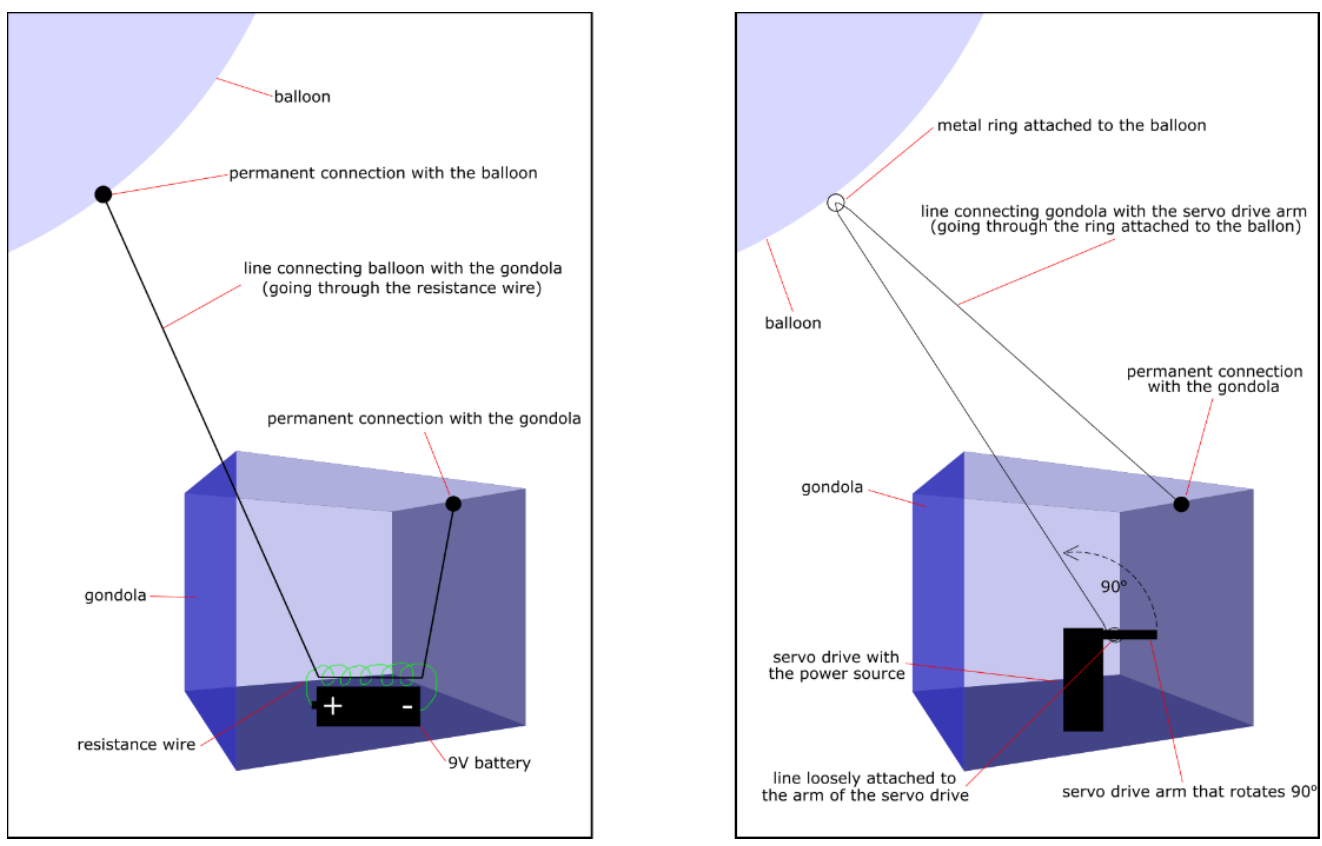

Fig. 4. Filling the balloon using helium cylinder at the HESOFF research area - Piaski Forest District.

Fig. 3. a) Concept I, which assumed usage of resistance wire connected to the battery and b) Concept II, which assumed usage of the servo drive. Source: Own elaboration. 
Lastly, balloon was permanently attached to the gondola, and despite the above-mentioned possible negative scenarios, the balloon burst, due to the pressure difference at the height of several kilometers, was assumed. In order to eliminate the risk that the balloon would stop rising and would start drifting at a constant altitude, more helium was used than the manufacturer recommended (+ 15\%). The issue of cutting off the balloon after reaching the required height is a rather complex problem. Literature sources present a description [13] of the situation for a much larger scale (balloon with a capacity of $1040 \mathrm{~kg}$ ). During the described flight, several balloon cut-off mechanisms failed simultaneously (Chapter 4: The MANTRA balloon flight / $b$ The Balloon Flight). The efficient cutting off of the balloon failed with the use of: explosive devices, helium releasing valve, temporary cable cut-off mechanism, and even while firing from a CF-18 fighter aircraft.

During the test balloon mission, a GPS receiver with power supply - Energizer LA522 Ultimate Lithium LA522/9V battery was used. Purpose of it was to determine the height of the balloon at certain time points. The aim of such a solution was to measure the height and assess the interpretative potential of the film material on the given levels of heights, as well as to assess the impact of the atmosphere on the pixel values recorded by the camera [14]. Unfortunately, after finding the gondola, it turned out that the system had not registered the required data, and the cause was considered a power failure. In order to avoid similar problems in subsequent missions, it was decided to perform additional tests of devices in the cryochamber and to undertake a series of intensive tests of the efficiency of several types of batteries for extreme temperatures down to $-60^{\circ} \mathrm{C}$. The goal of such tests would be determining the electrical parameters of battery or battery packs, with and without radiators, during their operation in changing environmental conditions [15].

Among the initial assumes of the project team, the usage of a lightweight Redleaf RD32 II camera was also considered. Unfortunately, during the tests, it turned out that the camera does not have the function of taking a series of photos. An attempt was made to create a dedicated program that triggers the shutter of the camera every 4 seconds, but the camera was unable to continuously and efficiently save data on the SD Card (MicroSD Class 10). In the end, the decision was made to replace the Readleaf RD32 II camera with a GoPro Hero 3 Silver camera, which is characterized by a greater resistance to external conditions and, at the same time, has merely a slightly higher own weight.

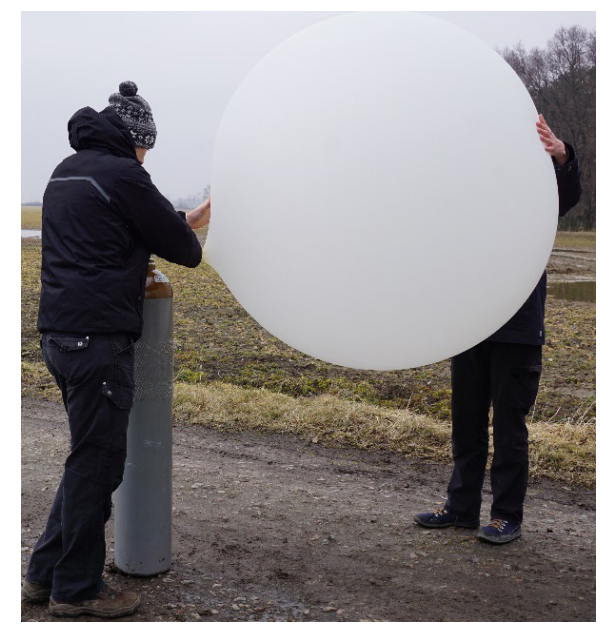

Fig. 4. Filling the balloon using helium cylinder at the HESOFF research area - Piaski Forest District. 


\section{RESULTS}

The total flight time was 1 hour and 36 minutes (including raising and the falling of the gondola). The landing took place $61 \mathrm{~km}$ from the place of start, in resort Garki (woj. wielkopolskie). The balloon's coating was torn, due to the pressure difference, at an approximate height of $17-18 \mathrm{~km}$. The gondola dropped with the balloon coating, which significantly exceeded the maximum capacity of the parachute. Nevertheless, casing made of foamed polystyrene was not seriously damaged, and only a small crack was observed. The landing took place in a cultivated field, relatively close to the road, so finding the equipment did not cause any issues. Thanks to the GPS SPOT Gen3 Tracker, the gondola was found immediately after, the place indicated by the Tracker was reached by the team. After the balloon was launched, its position was recorded every 2.5 minutes, and the flight route was observed in the SPOT service. However, a signal was lost a few minutes after the start. The balloon probably reached a height of $6500 \mathrm{~m}$ AMSL, at which (according to the manufacturer's specification) the device stops recording its position.

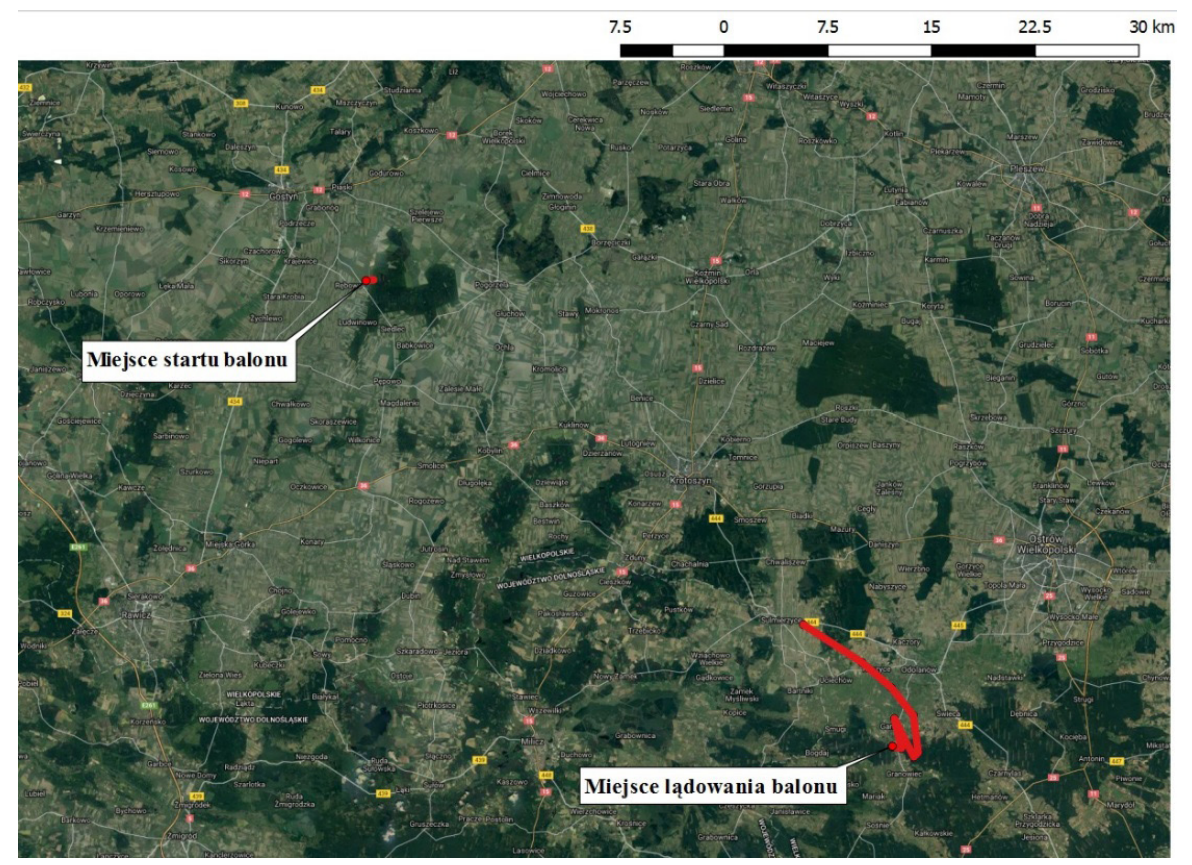

Fig. 5. The balloon flight route marked on the orthophotomap. Lack of continuity of the red line, which connects the points of the registered balloon position, results from the fact that communication with the GPS Tracker has been lost.

The basic GPS module did not work properly, so it was not possible to determine the exact height at which the balloon was raised. Despite the lack of telemetry data, an attempt has been made to estimate the theoretical height based on the received video material and input data. The theoretical rising height was calculated on the basis of the speed specified by the balloon's manufacturer $(6 \mathrm{~m} / \mathrm{s}$ was assumed) and the length of the recording - 52 minutes. Theoretical rising height $(18720 \mathrm{~m})$ was calculated using basic distance formula . To prevent similar occurrence in future mission, it is necessary to implement dedicated measuring devices adapted for the actual conditions and mission purpose. 
Other than satellite measuring methods, should be considered (barometric methods for example). To meet requirements of the specific mission it is also advisable to integrate various measuring methods [16], but this would be strictly dependent on load capacity of the balloon. The bursting of the balloon and the fall of the gondola, unfortunately, have not been recorded due to the low battery capacity in the camera and extremely low temperature conditions. Selected frames from the recorded film are presented in figures 6 and 7.

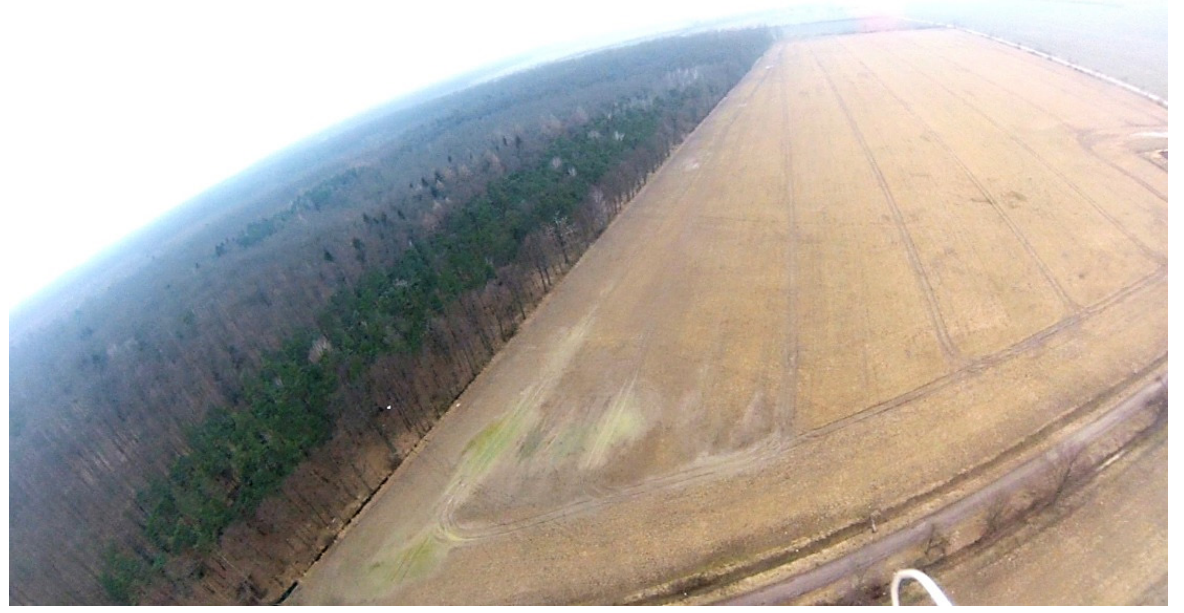

Fig. 6. Image registered a moment after the start. On the left, the forest covered by activities of HESOFF project is visible.

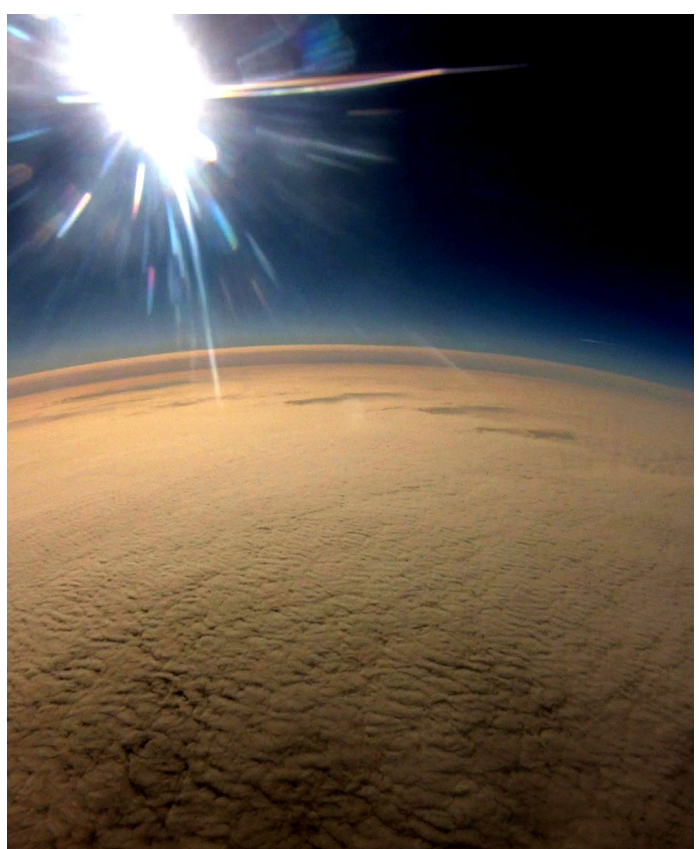

Fig. 7. Image registered above the level of clouds, at an altitude of approx. $16 \mathrm{~km}$. 


\section{CONCLUSIONS}

The aim of the test flight in the stratosphere over the research areas of the HESOFF project in the Piaski Forest District (carried out before the beginning of the oaks season in 2018) was to test the operational capabilities of balloon stratospheric missions and to check the interpretative potential of RGB images [17].

- During the flight, basic information necessary to perform an operational, long-endurance flight in the stratosphere depicting the research areas of the HESOFF project was collected. An additional test with usage of stratospheric balloon and mounted multisensor platform is planned after the beginning of the growing season and the development of the first leaves. The goal of a long-endurance mission in the stratosphere is, among others, to obtain material validating the usefulness of the methodology for assessing healthiness of oak stands on the basis of images obtained from lower ceilings using a multisensor platform.

- The test flight of the stratospheric balloon ended with partial success. The balloon launch was successfully carried out and the gondola was located after the landing. GoPro camera registered about $55 \%$ of the total flight time. For the purpose of planned future flights, it is necessary to improve important technical issues, such as the correct synchronization of the GPS receiver with the camera and power supply, which will enable cyclical registration of altitude during the whole flight and registration of the maximum height reached by the balloon. Thanks to the regular recording of all data during the flight, it would be possible to calculate, among others, the detailed flight path of the balloon in the vertical datum. In addition, it would improve the analysis of the interpretative potential of the acquired photos for the given ceilings.

- It is also necessary to consider the concepts of cutting off the balloon from the gondola (a servo drive with a mounted blade to cut the line, for example), other than the ones considered so far. It is important to disconnect the balloon after a certain time or altitude in an efficient and controlled manner. The use of efficiently operating, even in extreme weather conditions, solutions will allow for better control over the flight and will additionally enable the safe use of a balloon with a higher load capacity, e.g. $1000 \mathrm{~g}$ instead of $250 \mathrm{~g}$. It is worth noting that automatic activation device for skydiving would be very useful here, as a proper solution for cutting off balloon mechanism. Relatively small dimensions of parachute cutter allow to use it even in the small-scale missions and its reliability and strength (adapted for cutting loops and ripcords) brings new opportunities in the area of separating balloon from gondola. The issue to consider is the integration of the cutter with power supply and GPS receiver, that would allow cutting off the balloon within specific period of time or at the specific altitude.

- The solution proposed by the project team is scalable, thus increasing the scale of the mission and using balloon with a higher load capacity, gives the possibility of installing very advanced equipment. Given equipment can enable for example advanced measurements of ozone layer concentrations in regards of nitrogen and chlorine compounds. In case of using the camera acquiring pictures in a given, fixed time interval, it is necessary to ensure a stable flight of the gondola. For this purpose a dedicated connection should be implemented between the gondola, parachute and the balloon itself. During the test mission, the balloon was tied to the gondola with a single line, tied on the middle of the gondola cover, which significantly reduced the stability of the flight and the quality of the photos (large angular and linear movements).

- Aerial and satellite images are the basis for the very wide range of environmental analysis. Proper interpretation and data processing can lead, among other, to water quality study, biomass analysis, 
oaks health state evaluation or assessment of crops development. The resulting material from the GoPro camera is of moderate quality, and with a stable balloon flight, the photos obtained this way can be a high quality input product for selected studies. Photos taken from the balloon can be just as useful as aerial and satellite photos. The lifting capacity of unmanned platforms is very limited, so an appropriate selection of on-board sensors should always be ensured. It can therefore be postulated that one of the conditions for obtaining a good quality final material is the use of a balloon with increased load capacity ( $>250 \mathrm{~g}$ ), which will enable the installation of appropriate data acquisition equipment (with the required spectral resolution and geometric resolution) and the necessary additional accessories enabling safe and effective flight.

- Monitoring of vast expanses of forest and implementing environmental analysis (including the health assessment of forest stands), with the use of imaging from the stratosphere brings series of positive aspects, but there are some restrictions in the usage of this methodology. As figure 7 shows, obtaining data from the ceiling of several kilometers is strictly dependent on actual weather conditions, such as cloudiness hindering direct observation. To reduce these limitations, long-endurance mission that allows for constant observation of the given area, should be considered. In addition, such observations may be supported by photogrammetric flights from lower ceilings if more detailed and/or more frequent data is required. It is also worth mentioning that the ceiling of the stratosphere gives sufficiently wide access to the energy of the sun, which in turn gives the possibility of equipping the multisensor carrying system with photovoltaic panels.

\section{REFERENCES}

[1] Kotlarz J. and Zalewska N., 2017, "The possibility of ultraviolet Enceladus' observations from stratospheric balloons" Transactions of the Institute of Aviation.

[2] Morgała A., Kozak Z., Moszumański Z. and Szczepański J., 2003, 2008, „Samoloty w Lotnictwie Polskim” (ang.: „Airplanes in Polish Aviation”), http://www.samolotypolskie.pl/samoloty/3124/126/WBS-Gwiazda-Polski

[3] Yunpeng M., Jun H. and Mingxu Y., 2018, "A Novel Technique for Predicting the Thermal Behavior of Stratospheric Balloon" Hindawi, International Journal of Aerospace Engineering, Volume 2018, Article ID 7806036, 10 pages, https://doi.org/10.1155/2018/7806036

[4] Grzegorzewski J. and Królikiewicz T., 2006, "80 years of the Institute of Aviation" Scientific Library of the Institute of Aviation, Warsaw, page 120.

[5] Safonova M., Nirmal K., Sreejith A. G., Satpodar M., Suresh A. ..., 2016, "Measurements of Gondola Motion on a Stratospheric Balloon Flight" IIA Technical Report Series No. 16, pp. 1-9.

[6] Kacprzak M. 2016 „Application of GPS receivers and inertial measurement units to photo acquisition with use unmanned aerial vehicle (UAV)" Transactions of the Institute of Aviation.

[7] Commission Implementing Regulation (EU) No 923/2012 of 26 September 2012 laying down the common rules of the air and operational provisions regarding services and procedures in air navigation and amending Implementing Regulation (EU) No 1035/2011 and Regulations (EC) No 1265/2007, (EC) No 1794/2006, (EC) No 730/2006, (EC) No 1033/2006 and (EU) No 255/2010.

[8] Kacprzak M. and Wodziński K., 2016, „Execution of photo mission by manned aircraft and unmanned aerial vehicle" Transactions of the Institute of Aviation No 2(243), pages 130-141.

[9] Kacprzak M., Kotlarz J., Kubiak K., Rotchimmel K. and Tkaczyk M., 2018, „Methodology for estimating defoliation of Quercus Robur L. on the basis of reflectance analysis in the range of 
0.64-0.73 $\mu \mathrm{m}$ ” Industrial Institute of Agricultural Engineering, Agricultural, horticultural and forestry technology, 2018/2.

[10] Czapski P., Kacprzak M., Kotlarz J., Mrowiec K., Kubiak K. and Tkaczyk M., "Preliminary analysis of the forest health state based on multispectral images acquired by Unmanned Aerial Vehicle" Magazine Folia Forestalia Polonica Edition 3, Volume 57, Pages 138-144.

[11] Czapski P., Dorosz K., Kacprzak M., Korniluk T., Kotlarz J., Mazur A. ... and Rotchimmel K., 2016, „Acquisition and processing of aerial and satellite data by a research team of the Remote Sensing Department in Institute of Aviation” Surveying Review, 88(3), 4-9.

[12] Article of the University of Technology in Gdańsk, 2015, „W niedzielę studenci przetestują balon stratosferyczny" (ang.: "Students will test the stratospheric balloon on Sunday"),

[13] https://pg.edu.pl/aktualnosci/-/asset_publisher/hWGncmoQv7K0/content/w-niedziele-studenci-przetestuja-balon-stratosferyczny

[14] Strong K., Bailak G., Barton D., Bassford M. R., Blatherwick R.D., ... (2005). "MANTRA - A Balloon Mission to Study the Odd-Nitrogen Budget of the Stratosphere” Atmosphere-ocean 43(4).

[15] Mazur A., Kacprzak M., Kubiak k., Kotlarz J. and Skocki K. 2018 „The influence of atmospheric light scattering on reflectance measurements during photogrammetric survey flights at low altitudes over forest areas” Forest Research Papers 79 (1) 2018.

[16] Mazur A., Korniluk T. and Domański R., 2017, „Measuring and testing the parameters of a battery pack designed for powering unmanned aircraft systems at various temperatures" Transactions of the Institute of Aviation No 3(248), pages 46-62.

[17] Popowski S., 2011, „Verification of the idea of altitude and rate of climb measurement in selected aircraft" Transactions of the Institute of Aviation No 221, pages 143-160.

[18] Kotlarz J. and Kacprzak M. 2017, „Species diversity of forest stands estimation algorithm using RGB images of the tree crowns" Measurements Robotics Automation 2017/3, Volume 223, Pages 59-66.

\section{PRZYGOTOWANIE I WYKONANIE TESTOWEGO LOTU LEKKIM, BEZZALOGOWYM BALONEM STRATOSFERYCZNYM Z ZAMONTOWANĄ KAMERĄ GOPRO ORAZ ANALIZA OTRZYMANEGO MATERIAEU}

\section{Streszczenie}

Niniejsza publikacja zawiera opis przygotowania jak i samego wykonania testowego lotu balonem stratosferycznym z zamontowaną kamerą GoPro Hero3. Opisany w niej został wykorzystany sprzęt, jego parametry, rola w powodzeniu misji oraz trudności i ograniczenia jakie zespół napotkał w trakcie przygotowań i realizacji lotu. W misji brał udział sześcioosobowy zespół inżynierów i naukowców Zakładu Teledetekcji, którzy zaangażowani również byli w realizację projektu LIFE - HESOFF. Jednym 
z podstawowych celów projektu HESOFF było pozyskiwanie zdjęć lotniczych na terenie płyty Krotoszyńskiej (woj. wielkopolskie) z wykorzystaniem Bezzałogowego Statku Powietrznego (BSP) i realizowanie zdalnego monitoringu drzewostanów dębowych. Podstawowym celem dla eksperymentalnego lotu balonem, z kolei było: sprawdzenie technicznej zdolności operacyjnej oraz zdobycie doświadczenia w planowaniu i realizacji tego typu projektu. W trakcie wznoszenia balonu zebrano materiał wideo w postaci nagrania oraz wykonano analizę otrzymanych wyników. Na podstawie zebranych informacji przedstawiono wnioski dotyczące możliwości realizacji długotrwałego lotu w stratosferze obrazującego (za pomocą platformy wielosensorowej) powierzchnie badawcze projektu HESOFF. Etapy realizacji przedstawionej misji podzielono na następujące części: przygotowanie do lotu wraz z kompletowaniem sprzętu i niezbędnych dokumentów (zgłoszenie lotu), realizacja właściwa lotu rozumiana jako wypuszczenie balonu i identyfikacja miejsca w którym spadł sprzęt oraz przeanalizowanie otrzymanych wyników i przedstawienie wniosków.

Słowa kluczowe: balon stratosferyczny, stratosfera, lot fotogrametryczny, GPS, Bezzałogowy Statek Powietrzny

This paper has been prepared as a part of the implementation of the HESOFF (LIFE11 ENV/PL/000459) project, co-financed by the European Commission within the LIFE Instrument. Acknowledgments are addressed to the project team that was carrying out the field mission within the given project: Mariusz Kacprzak, Karol Rotchimmel, Karol Bęben, Marcin Spiralski, Jan Kotlarz and Krzysztof Wypych. 